\title{
The Saudi State as an Identity Racketeer
}

\author{
BEN RICH $^{\mathrm{a}}$ \& BEN MACQUEEN ${ }^{\mathrm{b}}$
}

a \& b Monash University, Clayton, Australia

\begin{abstract}
Although substantial research has examined the Saudi state's symbiosis with the Islamic revivalist movement commonly known as 'Wahhabism', few studies have considered how the dynamics of state formation underpin this relationship. This article argues that a continuous and circular political logic has sat behind the Saudi state's patronage of the revivalist movement since 1744 and proposes a four-stage model that explains how and why the regime has maintained this support over this prolonged period. This article first outlines this model, then presents a detailed analysis of its persistent presence in the development of Saudi state authority in order to highlight the recurrent manner by which the state often has constructed the spiritual concerns of revivalists to counter challenges to its authority, a pattern demonstrated most recently during the Arab Spring and the war in Yemen. The effects of this model will continue to shape the decisions, policies and perceptions of the Saudi political elite for the foreseeable future.
\end{abstract}

Keywords: Charles Tilly; Identity; Religious revivalism; Saudi Arabia; State building; State protection racketeering; Wahhabism

Since first emerging in the eighteenth century, Saudi governance has been synonymous with the co-option of the Najdi religious revivalist movement to achieve political legitimacy and 
durability. ${ }^{1}$ Through its patronage of the movement in 1744 , an otherwise unremarkable clan of oasis nobility was able to begin building a state that eventually would project over much of the Arabian Peninsula and which has persisted, albeit with two brief interruptions, ever since. $^{2}$ Although this link between regime and religion universally is acknowledged in the literature on the Saudi state, ${ }^{3}$ few efforts in social science have sought explain the deeper logic of instrumentality behind it. ${ }^{4}$ Although historians, theologians and legal scholars have interrogated this relationship, we have minimal understanding as to how this operates as a process of politics or governance or how the assumptions of such a process may help to predict future state behaviour.

This article investigates whether there has been a continuous political logic behind the Saudi state's patronage of the revivalist movement over the past three centuries. It proposes a new conceptual model of this interplay that follows the logic of the state protection racketeering theory proposed by Charles Tilly, ${ }^{5}$ with physical risk substituted by ontological threat. It argues that all incarnations of Saudi governance have sought to offer protections to the religious revivalist Wahhabi identity, while fomenting conditions in which these same protections become desirable in order ultimately to strengthen and expand the state. The

Corresponence address: Ben Rich, Curtin University, Ben.rich@curtin.edu.au. Ben MacQueen, Monash University, Ben.macqueen@monash.edu

\footnotetext{
${ }^{1}$ Examples include Commins, D. (2006) The Wahhabi Mission and Saudi Arabia, (New York: Palgrave Macmillan).; and DeLong-Bas, N. J. (2004) Wahhabi Islam: From Revival and Reform to Global Jihad, (New York: Oxford University Press).

${ }^{2}$ Vassiliev, A. (2000) The History Of Saudi Arabia, (London: Saqi Books).

${ }^{3}$ See al-Atawneh, M. (2009) Is Saudi Arabia a Theocracy? Religion and Governance in Contemporary Saudi Arabia, Middle Eastern Studies, 45(5), pp. 721-37.and Alsaid, T. (2013) Relationship between state and religion in Saudi Arabia: the role of Wahabism in governance, Contemporary Arab Affairs, 6(3), pp. 376-403.

${ }^{4}$ Two exceptions to this have been Shahi, A. (2013) The Politics of Truth Management in Saudi Arabia, (Hoboken: Taylor and Francais). and Firro, T. K. (2013) The Political Context of Early Wahhabi Discourse of Takfir, Middle Eastern Studies, 49(5), pp. 770-89.

${ }^{5}$ Tilly, C. (1985) War Making and State Making as Organized Crime, in: Evans, P., Rueschermeyer, D. \& Skocpol, T. (eds) Bringing the State Back In, pp. 169-87 (Cambridge: Cambridge University Press).
} 
article begins by outlining the parameters of its proposed model. It then seeks to explain specific religio-political activities of the first, second and third states through the logic of the model. The article then concludes by showcasing the contemporary relevance of the model in the wake of the Arab Spring, arguing that a state-directed protection racket built around a revivalist-type identity continues to persist today.

\section{State racketeering}

The Saudi state's sponsorship of religious revivalism can be interpreted as a protection racket built around a paradoxical simultaneous construction of and shielding against ontological insecurity, a concept defined as an '[in]security of being, a [lack] of confidence and trust that the world is what it appears to be. ${ }^{6}$ This can be observed in the regime's perennial emphasis of itself as the principal benefactor of the Wahhabi movement since 1744, while simultaneously placing the identity of that same movement in a state of insecurity and offering protection against this condition for various extractive prices: taxation, the provision of troops and, most importantly, compliance with the centre and its goals. The general trend of this racket has been the growth and maintenance of state legitimacy, or 'a psychological property of an authority, institution, or social arrangement that leads those connected to it to believe that it is appropriate, proper, and just. ${ }^{7}$ This has enabled the Saudi regime to cultivate and consolidate state power over an expansive territory across a prolonged period to an extent unseen in the peninsula since the early Islamic Empire. This, in turn, has enabled the regime to maintain and reinforce the racketeering cycle itself, as considerable elements of extraction are redirected to ensure perpetuation.

\footnotetext{
${ }^{6}$ Kinnvall, C. (2004) Globalization and Religious Nationalism: Self, Identity, and the Search for Ontological Security, Political Psychology, 25(5), pp. 741-67.

${ }^{7}$ Tyler, T. R. (2006) Why people obey the law, (New Jersey: Princeton), p. 357
} 
Based on the European experience, classical racketeering theory argues that the emergence of the modern state ${ }^{8}$ was the inadvertent outcome of pre-state elites establishing criminal protection rackets over their constituencies. These provided protections against international threats that these same rulers were complicit in generating. Despite being fought largely for the pursuits of noble and mercantile elites, the conflicts of the sixteenth and seventeenth century Europe disproportionately impacted civilians. ${ }^{9}$ This, Tilly suggests, created a growing demand for reliable protection against outsiders. In response, many of the same war-making elites began to offer a military and policing shield for such a demand, as such protections helped to generate substantial return of extraction, notably taxation, conscription, and loyalty to the centre, which could help to fund further efforts of conquest, personal power and ultimately led to an inadvertent process of state building. The benefits and success of this strategy in turn incentivised the subsequent creation or fabrication of threats of external violence by these same protectors in order to facilitate further extraction, a cycle that would allow for the creation of permanent institutions of protection and the growth of the modern state through a process of racketeering. ${ }^{10}$

At first glance, Tilly's theory appears to lack relevance to the Saudi case, as little research indicates that a condition of wide-spread concern over the physical threats posed by outsiders preluded the formation of the first state in Najd. ${ }^{11}$ Indeed, Central Arabia was insulated from external wars, with only ephemeral, limited conflicts waged between isolated

\footnotetext{
${ }^{8}$ Defined by Michael Mann as a large-scale territorial entity that possesses a centralised and institutionalised core holding a monopoly on authoritative rule-making and physical violence in Mann, M. (1984) The autonomous power of the state: its origins, mechanisms and results, European Journal of Sociology / Archives Européennes de Sociologie, 25(02), pp. 185-213.

${ }^{9}$ Garfield, R. M. \& Neugut, A. I. (1997) The Human Consequences of War, in: Levy, B. S. \& Sidel, V. W. (eds) War and Public Health, (New York: Oxford University Press), p. 30. and White, M. (2012) Selected Death Tolls for Wars, Massacres and Atrocities Before the 20th Century. Available at: http://necrometrics.com/pre1700a.htm\#30YrW, accessed 24/03/2015.

10 Tilly, War Making and State Making as Organized Crime, p. 171.

${ }^{11}$ al-Juhany, U. M. (2002) Najd before the Salafi Reform Movement: Social Political and Religious Conditions during the 3 Centuries Preceding the Rise of the Saudi State, (Berkshire: Ithaca Press).
} 
oases and Bedouin communities. ${ }^{12}$ A zeitgeist of international threat against which elites could construct a regime of racketeering in response thus does not seem a convincing explanation for the emergence of the Saudi regime. However, whilst Najd lacked the necessary precursors to support a pure replication of Tilly's theory, it did possess a widespread perception of risk open to exploitation in the Wahhabi movement. Wahhabism emerged in Central Arabia during the 1730s, in response to a wide-spread sense of existential anxiety in considerable portions of the region's population in a manner consistent with observations made of numerous religious nationalist movements by both Catarina Kinnvall and Mark Juergensmeyer. ${ }^{13}$ Specifically, the movement's raison d'être was the elimination of religious pluralism, which was seen as creating epistemic uncertainty, corrupting the religion and interfering with the divine simplicity of the oneness of the God. Initially, this fixated on local paganism and Sufism in Najd, before later shifting to securitise a much more diverse array of groups, including other schools of Sunni thought and monotheistic faiths such as Christianity. Central to revivalist identity was a utopian hope for the restoration of society in imitation of the early Muslim imperial period; a reordering that would provide existential certainty, eliminate unnecessary complexity, assign sanctified significance to ends and provide canonised means with which to achieve them in a legible and accessible manner. ${ }^{14}$ Practices challenging the absolutist epistemic claims of revivalist orthodoxy were vilified as idolatrous and polytheistic and warranting dramatic responses, often violence. ${ }^{15}$ Revivalist elites commonly argued that those who undertook such practices were not simply

\footnotetext{
12 Vassiliev, The History Of Saudi Arabia, p. 6.

${ }^{13}$ See Kinnvall, C. (2004) Globalization and Religious Nationalism: Self, Identity, and the Search for Ontological Security, Political Psychology, 25(5), pp. 741-767. and Juergensmeyer, M. (1994) Religious nationalism confronts the secular state, Oxford University Press).

${ }^{14}$ Niblock, T. (2004) Saudi Arabia: Power, Legitmacy and Survival, (Hoboken: Taylor and Francais), p. 25.

15 al-'Uthaymin, A. A. S. (2009) Muhammad ibn 'Abd al-Wahhab: The Man and his Works, (London: I.B. Taurus and (C), p. 24.
} 
disinterested outsiders, content to live apart from the revivalist community but nefarious saboteurs, determined to undermine the foundations of Islam.

Writing in the early nineteenth century, for example, the prominent scholar, Sulayman ibn Abdallah, compared the Hanafi Egyptians to the polytheists of early Islamic legend, arguing that such groups 'would never be satisfied with the Prophet until he would follow their religion, and bear witness that they are upon the truth. ${ }^{16}$ Revivalism in this form represented as a 'securitisation of subjectivity, ${ }^{, 17}$ where alternative claims to truth from nonadherent religious communities raised fears of a loss of order, continuity, morality and meaning. Such epistemic threats were felt to undermine the essential principals of Islam and the associated identity built around them by conservative Sunnis, many of whom gravitated to the movement as a means to reassert their sense of self. As Jennifer Mitzen puts it, individuals 'need to 'make sense of their world', and when...meanings are unsettled [they] suffer...psychological stress. ${ }^{18}$ For revivalists, the existence of sectarian diversity unsettled these meanings and the Saud-revivalist alliance served to create certainty. From the outset of this relationship, the state committed itself to guarding revivalism from non-orthodoxy by supporting the enforcement of Wahhabi doctrine and suppressing or eliminating competing sectarian claims in the public sphere, creating a utopian safe space in which revivalist identity would be unchallenged and hegemonic. In exchange, revivalists were expected to fulfil the regime's extractive demands: troops, taxation and compliance with the centre - although only the latter would be relevant by the later twentieth century. While such an arrangement superficially may appear as a simple patron/client relationship, such a characterisation

\footnotetext{
${ }^{16}$ Abdallah, S. (N/D) The Evidences for the Ruling Regarding Alliances with the Infidels and Matters Related to It., (at-Tibyan Publications), p. 82.

${ }^{17}$ Kinnvall, Globalization and Religious Nationalism: Self, Identity, and the Search for Ontological Security, pp. 741-67.

${ }^{18}$ Mitzen, J. (2006) Ontological Security in World Politics: State Identity and the Security Dilemma, European Journal of International Relations, 12(3), p. 349.
} 
obfuscates how the regime sought to create demands for its protection services and how, paradoxically, it often existed as the greatest source of threat to the very revivalist identity it claimed to defend.

\section{A Model of State Identity Racketeering}

This mode of identity racketeering that the Saudi state employs effectively functions as a positive feedback loop as shown in figure one below. This cycle has four sequential stages that, collectively, have legitimated the regime with a domestic revivalist client community, a key structure of extractive support that has been integral to the formation and growth of the state since its first inception in 1744. The first stage of the model concerns the state's offer of protection against ontological insecurities associated with revivalism. Utilising centralised organisation in governmental institutions, sanctioned and complicit Islamic scholars, as well as through collective demonstrations of piety and physical domination, the state has presented itself as a solution to the existential uncertainties posed by divergent sectarian groups and socio-cultural shifts away from traditionalism. Originally, this offer focused on shielding against local passive pagan and Sufi groups in Najd. Following the first Saudi state, however, the subject necessitating protection was shifted to external actors that threatened the political interests of the state. Offered protections were often reflexively formed in response to these varying interests, but invariably, all invoked a commitment to maintaining the homogenous primacy of revivalist traditionalism and ensuring a shield against the corruptive influence of these other communities.

Stage two occurs the acceptance of the state's offer by the revivalist community as a whole. The offer must be presented in such a way that it is found not only convincing by complicit revivalist elites, but also wider adherents. This often transpires thanks to the complicity of the former, who present the offer to the masses through an interpretation of 
religious idiom favourable to the regime's goal. Such a successful transaction legitimates the state by reaffirming the movement's dependency on its paternalism and ensuring access to required resources and a stalwart support base it can rely on in times of crisis and upheaval.

The third stage of racketeering sees the use of centralised organisation to spread and maintain the revivalist identity within the client population, ensuring the existence of the movement across concurrent generations and maintaining demands for ontological protections. Since 1744, the state has achieved this through a number of methods, including financing religious educators; constructing infrastructure, including schools and mosques; providing material incentives for religious piety and commitment in citizens; and maintaining a perennial 'mystification' of the public sphere; and preventing the existence of organised alternatives to revivalism. ${ }^{19}$ Central co-ordination was considerably limited until the twentieth century and prior to this period the individual actors involved in these praxes were often afforded a great deal of autonomy in achieving their mission. Nevertheless, the Saudi state remained the critical enabler to the revivalist movement's prosperity facilitating many elite scholars predisposition to supporting the centralisation of authority. The importance of the state in ensuring revivalist success was most clearly demonstrated in the movement's fortunes under other regimes who temporarily dominated Najd, such as the Ottomans and the Rasheeds, where the doctrine and its proponents were marked by decline and socio-political marginalisation. ${ }^{20}$

The fourth stage relates to the sources of insecurity for the propagated revivalist identity, the largest contributor to which has been the state. As indicated above, this takes direct and indirect forms. Deliberate stimulation of threats has existed from the very beginning of the state-revivalist alliance through the construction of political rivals as

\footnotetext{
${ }^{19}$ al-Rasheed, M. (2007) Contesting the Saudi State, (New York: Cambridge University Press), p. 61.

${ }^{20}$ Wagemakers, J. (2012) The Enduring Legacy of the Second Saudi State: Quietist and Radical Wahhabi Contestations of al-Wala' wa-I-Bara', Middle East Studies, 44(1) pp. 93-110.
} 
epistemic threats. Since the nineteenth, however, indirect factors associated with misalignment between ideological fidelity and pragmatic state behaviour have become an increasingly prominent source of insecurity for revivalists as a result of the state's maturation and socialisation within the international system. Pragmatic regime policies promoting traditional security, economic interdependence and interfaith relations have repeatedly undermined the traditionalism central to the epistemic security of many revivalists, a dynamic which, at face value, would appear to weaken the foundations of their relationship with the state. Nevertheless, because of its dominant socio-religious status and ability to depend on the support of Islamic scholars whose status and privilege are dependent on its success, the state is able to deflect critiques based on this and portray itself as a force for revivalist continuity, rather than a saboteur of that same condition.

From here, the racketeering cycle starts anew, with the state offering renewed protections to the revivalist community as a whole from threats it itself is often the chief architect of. While this cycle has not always operated smoothly, it is telling that during its entirety of its history, the only large and cohesive revivalist bloc to outright break from the racket cycle were the rebellious $I k h w a \bar{n}$. For the majority of revivalists under Saudi rule, the acceptance of this cycle has been a perennial given since the racket was fully asserted during the nineteenth century.

\section{The first state (1744-1818)}

The period of the first Saudi state saw the manifestation of elements of all four components of the protection racketeering model. This began with the first stage, as the leadership of the Saudi settlement of al-Diriyah offered protections to adherents of the revivalist movement, 
after the latter had repeatedly experienced exile and ostracisation for their radical views in other parts of Najd. ${ }^{21}$ Alongside providing physical security to the movement, the Saudis committed themselves to supporting the spread of revivalist doctrine and maintaining its dominance in any public sphere under their sovereignty, a pledge that enabled the regime to initiate an expansive conquest of Najd and its surrounds. As stage two of the model predicts, the movement was quick to accept such provisions and provided religious legitimation, funding and troops for Saudi expansionist conquests, sanctifying these activities as a holy task to purify and defend a besieged Islam and demonising the political foes of the regime as polytheists and unbelievers who sought to undermine the religion. ${ }^{22}$

The third stage was also readily observable under the first state. The Saudi regime dedicated considerable energies in propagating revivalism. During expansion, the government used the legitimacy derived from its support of the revivalist mission to override systems of local tribute with a centralised system of religious tax. Through a portion of this growing revenue stream, support was lent to the revivalist elite to further spread and impose orthodoxy. Revivalist scholars and judges no longer drew salaries from local benefactors, but became employees of the central regime and were ensured privileged roles in the new order. ${ }^{23}$ The regime funded the construction of religious infrastructure, such as mosques, that served as hubs of demagoguery. Up until this point, the social, political and economic environment of Najd for centuries had been typified by fragmentation, ${ }^{24}$ but alongside conquest, inducement and inter-tribal alliance building, the use of third stage racketeering helped grow

\footnotetext{
${ }^{21}$ Abd al-Wahhab, M. i. (2010) The Foundations of Islam: being a translation of Masa'il al-Jahiliyyah allati Khalafa fiha Rasulullah Ahla'l-jahiliyyah, (Birmingham: Dar as-Sunnah Publishers), p. 16.

22 Steinberg, G. (2006) The Wahhabi Ulama and the Saudi State: 1745 to Present, in: Aarts, P. \& Nonneman, G. (eds) Saudi Arabia in the Balance, (London: C. Hurst an Co.), p. 12.

${ }^{23}$ Kjorlien, M. L. \& Michele, M. L. (1994) State and Religion in Saudi Arabia, The Arab Studies Journal, pp. 36-64.

24 al-Juhany, Najd before the Salafi Reform Movement: Social Political and Religious Conditions during the 3 Centuries Preceding the Rise of the Saudi State.
} 
the movement and galvanise many disparate actors, allowing for the assertion of a more consolidated and coordinated authority across the region. ${ }^{25}$ This represented an 'astonishing rupture' with historical trends in the region as, by 1805 , the regime had conquered the majority of the Arabian Peninsula under its religious mandate, including Mecca and Medina, in the process challenging the authority of the Ottoman Empire itself. ${ }^{26}$

Although the fourth stage of racketeering was to manifest under the first state, it functioned in a less pervasive form than it would under subsequent regimes. The state actively supported the construction of its political foes as rivals to the integrity revivalism; groups who otherwise likely would have been disinterested in the movement, had it not been mobilised against them behind an aggressive and expansive state. Nevertheless, it wasn't until the second state that the fourth stage stimulation would manifest in full, with deliberate stoking of revivalist insecurities paired with an indirect dynamic in which pragmatic, aideological decisions of Saudi policy makers had a side-effect of fomenting conditions for ontological anxiety. The reasons behind the lack of this element most prominently were tied to the unique international conditions in which the first state operated, as it expanded in a relative power vacuum and was not forced to make the concessions and accommodations to external actors that its predecessor regimes were forced to do. Having few actual relations with external states, there was little cause for dissonance between its commitments to the revivalist movement and its behaviour as a state.

From here, the state would begin the cycle of racketeering anew by offering growing regimes of protection to adherents as it expanded its territories. Perhaps the most controversial of these were the systemic campaigns of violence aimed at eliminating symbolic and physical representations of epistemic contestation. Upon seizing new

\footnotetext{
${ }^{25}$ al-'Uthaymin, Muhammad ibn 'Abd al-Wahhab: The Man and his Works, p. 58.

${ }^{26}$ Commins, The Wahhabi Mission and Saudi Arabia, p. 32.
} 
settlements, the regime oversaw adherents in enacting iconoclasm, destroying artefacts, shrines and other items that were seen to challenge the monotheistic claims of revivalism. Similarly, individuals seen to be corrupting the religion, be they Sufi, pagan, Shi'a or nonorthodox Sunni, were often the recipients of harsh, large-scale violence organised by the state, perhaps the worst instance of which occurred during a raid on the Shi'a city of Karbala in 1802, resulting in thousands of civilian deaths. ${ }^{27}$ Similar incidents were witnessed in towns such as Taif and Zubayr, with the violence rationalised through the rhetoric of religious protectionism in the service of revivalist identity demands. ${ }^{28}$ Here, supporting the assertions of Michael Vlahos, systemic violence became a celebration of identity, as competing structures of truth were stifled and stamped out, along with the associated doubts they presented to revivalism. ${ }^{29}$

\section{The second state (1824-1891)}

The unprecedented success of the first state's expansion would prove its undoing. Assertion of Saudi authority over Ottoman holdings in Mecca and Medina served to antagonise Constantinople and in 1811 Imperial forces landed in Western Arabia and gradually drove the Saudis back to Najd over the next seven years. This Saud-Ottoman war represented a manifestation of the fourth stage of racketeering, as the war-making activities of the state brought an otherwise disinterested Ottoman suzerain into violent contact with the revivalist movement. As stage one of the model predicts, scholarly elites complicit with the state portrayed the Ottomans not just as invaders, but as religious corrupters who sought to undo the regime and the mission. Referring to the Ottomans, the scholar Sulayman ibn Abdallah

\footnotetext{
27 An account of this translated by Mohammad Ballan is available at https://ballandalus.wordpress.com/2014/08/02/the-wahhabi-sack-of-karbala-1802-a-d/, accessed 05/01/2017.

${ }^{28}$ Trofimov, Y. (2007) The Siege of Mecca, (New York: Doubleday Broadway Publishing Group), p. 17.

${ }^{29}$ Vlahos, M. (2008) Fighting Identity: Sacred War and World Change (Westport: Praeger).
} 
wrote that 'the [unbelievers] will never cease fighting the Muslims until they turn them back from their [faith]. ${ }^{30}$ Revivalism under Ottoman rule thus be would compromised, and only supporting the current order under Saudi sovereignty could ensure the movement's prosperity and fidelity. Nevertheless, despite a prolonged resistance sustained in part by the revivalist call to arms, the superior Ottomans destroyed the last vestiges of Saudi statehood in 1818.

The Ottomans withdrew from Najd in only a few years and new Saudi authority reemerged in 1824, when Turki ibn Abdallah recaptured Riyadh. The position of the state was far weaker than its predecessor. Both a growing British presence in the peninsula's east and reinvigorated Ottoman activity to the north and west acted to undermine the state's sovereignty and prevented the expansionism in which both its predecessor and its successor had and were to engage. ${ }^{31}$ This was compounded further by the emergence of local competition in the form of the al-Rasheed clan out of Hai'l, who challenged the Saudis for control of Najd. In a perpetual state of besiegement, the disposition of the second Emirate was thus largely defensive in place of the revolutionary aggressiveness of its predecessor the objective being simply to maintain the integrity of the state, not expand its holdings.

Despite the new international constraints placed upon the second regime, it rapidly resumed its racketeering behaviour. As in stages one, two and three, the state successfully presented itself as a protector of the movement and used centrally directed resources harvested from this process both to spread religious doctrine and to maintain a revivalistdominant social sphere with other sectarian groups supressed. Revivalist elites continued to support the regime and delegitimise its opponents as sources of corruption. In one polemic, the prominent scholar Abdallah Abd al-Latif wrote that it was incomprehensible that 'that anyone would know [Islam]...yet would not have enmity against the [polytheists] (referring

\footnotetext{
${ }^{30}$ Abdallah, S. (N/D) The Evidences for the Ruling Regarding Alliances with the Infidels and Matters Related to It, p. 83.

${ }^{31}$ See Wynbrandt, J. (2004) A Brief History Of Saudi Arabia, (New York: Checkmark Books). \& Quataert, D. (2005) The Ottoman Empire, 1700-1922 (Cambridge: Cambridge University Press).
} 
to the Ottomans and British)]...whoever does not have enmity towards them, then it is not said that he knows [Islam] or acts upon it. ${ }^{32}$ The tone of revivalist discourse shifted in reflex to the political conditions of the state from one of conquest and expansion to one of holding the line against the idolatry of surrounding threats. ${ }^{33}$ Similarly, such polemics displayed increasing extraversion, as the primary rivals to the state now were international in nature, rather than parochial. Nevertheless, the content was essentially the same. The imperial actors confronting the second Saudi state were portrayed as potential sources of corruption to the religion, in a manner consistent with the characterisation of local Sufis, pagans and Shi'a under the first state. ${ }^{34}$

While the first three stages of the second state's racketeering cycle functioned in a manner consistent with the previous regime, the stimulation of revivalist insecurities under the fourth stage displayed new tendencies toward indirectness. Here, a new dynamic emerged around the dissonance between the state's pragmatic behaviour of survival and its commitments to protecting the integrity of revivalist identity. This manifested most prominently during the Saudi civil war after 1865, where two sibling claimants to the throne engaged in a prolonged struggle. Unable to overcome his brother, the Saudi emir Abdallah sought assistance from Ottoman forces in Baghdad to stabilise the state and shore up his own rule. While perhaps sensible from a perspective of realpolitik, this decision flagrantly contradicted the regime's commitments to maintaining the ontological securities of its revivalist constituents. Through its a-ideological behaviour of survival, the state indirectly was facilitating a major source of insecurity for revivalists. The most observable result to this was a schism amongst the revivalist scholars, many of whom began to question the

\footnotetext{
${ }^{32}$ Quoted in al-Maqdisi, A. M. (1984) Millat Ibrahim, (at-Tibyan Publications), p. 38.

${ }^{33}$ Commins, The Wahhabi Mission and Saudi Arabia, 40-70

${ }^{34}$ Firro, T. K. (2013) The Political Context of Early Wahhabi Discourse of Takfir, Middle Eastern Studies, 49(5), pp. 770-89.
} 
legitimacy of the regime and the authenticity of its commitment to the revivalist cause. While this disagreement remained largely academic and failed to translate to the wider revivalist community, it was characterised by its vociferous nature and even led to some scholars excommunicating one another in a manner previously reserved for the non-adherent sectarian communities the movement so loathed. ${ }^{35}$

Despite the potential disaster presented by this new face of the fourth stage of racketeering, the regime's offer of religious protection continued to be accepted by the majority of revivalists. Indeed, as Tarik K. Firro notes, as the state weakened from internal struggle, rival competitors and a devastating famine, religious invocations against the Ottoman and British forces became 'the main instrument to mobilise the masses' behind the regime. ${ }^{36}$ This tactic, however, ultimately would fail to sustain the second state, and its final vestiges were stamped out in 1891 by a briefly ascendant al-Rasheed state. ${ }^{37}$

\section{The Ikhwān and the failure of the cycle}

A third Saudi state re-emerged shortly after its predecessor's demise in 1902. The next three decades were spent expanding the territories and consolidating internal authority before gaining international recognition in 1932. Curiously, the first decade of reconstitution appears to have lacked racketeering behaviour, with the regime focused on cultivating intertribal alliances through shared economic and conventional security interests in a manner that defies the predictive power of the model. ${ }^{38}$ By 1912, however, the state had resumed racketeering. While this cycle occurred much as it had under previous Saudi regimes, it was not always

\footnotetext{
35 Steinberg, The Wahhabi ulama and the Saudi state: 1745 to the present, p. 19.

${ }^{36}$ Firro, The Political Context of Early Wahhabi Discourse of Takfir, Middle Eastern Studies, 49(5), p. 783.

${ }^{37}$ Scott, J. C. (1999) Seeing Like a State: How Certain Schemes to Improve the Human Condition Have Failed, (Yale: Yale University Press ).

38 Cronin, S. (2013) Tribes, Coups and Princes: Building a Modern Army in Saudi Arabia, Middle Eastern Studies, 49(1), p. 6.
} 
successful in its implementation. The most blatant case of this occurred with the sedentarization of the Najdi Bedouin and the state-backed drive to convert them to revivalism in a manner that, had it been successful, would have transformed them into a useful new client community of the racket. The nomadic Bedouin had long resisted Saudi authority and revivalist teachings. ${ }^{39}$ To counteract this, the state established a series of agrarian settlements in which intensive preaching was conducted by revivalist scholars. The nomads subsequently were driven to settle in these farmsteads through a combination of inducement and coercion, ${ }^{40}$ with some estimates suggesting that by 1921 , nearly 150,000 Bedouin out the entire total Najdi population of 250,000 had been settled. ${ }^{41}$ Many became enthusiastic supporters of the strict orthodoxy under the moniker Ikhwān. Their subsequent military activities played a crucial role in expanding Saudi territory and were undertaken in a manner consistent with the earlier conquests of the first state under the banner of religious expansion and purification. ${ }^{42}$ The conversion of the $I k h w \bar{a} n$ displayed many facets of previous instances of Saudi racketeering. Through this centrally directed scheme the state and compliant religious elites sought to propagate revivalism among the Bedouin as a means of instilling a demand for protection services. As the chief patron of the revivalism, the state naturally assumed the Ikhwān would accept it as the movement's protector.

Although the Ikhwān were successfully brought over to revivalism, however, they increasingly came to identify the pragmatic behaviour of the state as blatantly contradicting

\footnotetext{
${ }^{39}$ Scott, J. C. (1999) Seeing Like a State: How Certain Schemes to Improve the Human Condition Have Failed, (Yale: Yale University Press), pp. 53-146.

${ }^{40}$ al-Rasheed, M. (2002) A History of Saudi Arabia, (Cambridge: Cambridge University Press), p. 62.

${ }^{41}$ These statistics are only rough estimates drawn from Habib, J. S. (1978) Ibn Sa'ud's warriors of Islam: The Ikhwan of Najd and their role in the creation of the Sa'udi Kingdom, 1910-1930, (London: Brill). \& Keltie, J. S. \& Epstein, M. (1921) The Statesman's Yearbook, (New York: The Macmillan Company), p. 1348.

${ }^{42}$ Goldberg, J. (1982) The 1913 Saudi occupation of Hasa reconsidered, Middle Eastern Studies, 18(1), p. 21.
} 
the tenets of their newfound faith. Of particular contention was the fact that the regime tolerated non-orthodox Sunni and Shi'a populations and maintained friendly relations with foreign powers. While internal sectarian groups were disallowed from practice in the public space under Saudi rule, they remained crucial for the economic prosperity of the state ${ }^{43}$ and were generally compliant with its growing authority. ${ }^{44}$ This led the regime to turn a blind eye to many of the religious and cultural activities of such groups, provided they weren't undertaken overtly. ${ }^{45}$ Similarly, the experiences of the previous regimes made clear the necessity of forming amicable ties with powerful states such as Britain and the United States. Despite the pragmatism of these policies, however, their a-ideological nature seriously weakened the credibility of the offers under the first stage of racketeering for the Ikhwān, with the state seen as colluding with the very sources of insecurity it claimed to protect against. This grievance was exacerbated by the growing antipathy of the Ikhwān toward the regime, thanks to a number of other economic and political grievances. ${ }^{46}$ In late 1926 , the racketeering cycle collapsed, with the second stage failing to take hold as a number of Ikhwān leaders rejected the state's offer of protection in a list of charges that stressed its failure to safeguard revivalism. Among these indictments was Riyadh's insufferable diplomatic relations with infidel powers, as well as its ongoing toleration of the Shi'a. ${ }^{47}$ This dissonance between state activity and the Ikhwān's religious expectations contributed to a subsequent three-year rebellion beginning in 1927 . While the state would continue to sustain a cycle of

\footnotetext{
${ }^{43}$ Kostiner, J. (1990) Transforming Dualities: Tribe and State Formation in Saudi Arabia, in: Khoury, P. S. \& Kostiner, J. (eds) Tribes and State Formation in the Middle East, (Berkley: University of California Press), p. 234.

44 Matthiesen, T. (2015) The Other Saudis, (New York: Cambridge University Press), pp. 45-48.

${ }^{45}$ Kostiner, J. (1985) On instruments and Their Designers: The Ikhwan of the Najd and the Emergence of the Saudi State, Middle East Studies, 21(3), p. 299.

${ }^{46}$ See Toth, A. B. (2005) Tribes and Tribulations: Bedouin Losses in the Saudi and Iraqi Struggles Over Kuwait's Frontiers, 1921-1943, British Journal of Middle Eastern Studies, 32(2), pp. 145-67. and Commins, The Wahhabi Mission and Saudi Arabia, p. 90 .

${ }^{47}$ Vassiliev, The History Of Saudi Arabia, p. 273
} 
racketeering, the Ikhwān experience demonstrated the potential hazards that it could face from its own potential constituents if this loop was not managed effectively, issues hinted at, but never fully realised under the second state.

\section{Institutionalisation, Cold War Rivals and further Contradictions}

Following the surrender of the rebels, the regime entered a period of prolonged stability over the next three decades. Despite the disaster of the Ikhwān case, the state's behaviour as a racketeer continued throughout the 1930s. Following the discovery of large oil deposits in 1938, the protections offered increasingly institutionalised within the formal structures of the

state. ${ }^{48}$ A significant instance of this occured in 1940, with the establishment of an official religious policing organisation, known as the Committee for the Promotion of Virtue and the Prevention of Vice (CPVPV). Religious policing always had been central to the compact between the revivalist movement and the regime, but, prior to 1940, local scholars, who retained considerable personal autonomy despite drawing their salary from the state, generally directed this activity. While integral to the racket, the independence of these agents could lead to disastrous outcomes, as in the case of the Ikhwān, who had ultimately come to view themselves the true enforcers of revivalism. The creation of the CPVPV aimed to maintain the first stage offer of protections by the state, but was to be subordinated centrally within the regime's growing bureaucracy in a manner that limited the individual power and autonomy of religious enforcers. ${ }^{49}$ Although this did not end the personal influence of CPVPV officers, it emplaced institutional restrictions that ensured they were beholden to an authority above their own.

\footnotetext{
${ }^{48}$ Shahi, The Politics of Truth Management in Saudi Arabia, p. 170-71

${ }^{49}$ Lacroix, S. (2011) Awakening Islam: The Politics of Religious Dissent in Contemporary Saudi Arabia, (Massachusetts: Harvard University Press), p. 74.
} 
During the 1940s, 1950s and 1960s, numerous other formal religious organisations emerged, particularly in public morality, law and education - arenas crucial to sustaining the revivalist doctrine and projecting the state's commitment to the movement. This era culminated in 1972 with the foundation of the council of senior Islamic scholars, a body designed to advise the government authoritatively on religious issues and to provide revivalist sanction for state activities. ${ }^{50}$ Each of these religious organizations would further develop alongside other modernization initiatives undertaken during this period, while helping to maintain the state's longstanding offer to ensure revivalism would retain a place of privilege under Saudi rule.

As rentier largesse became a new feature of Saudi rule, the needs of extraction through racketeering lessened to solely that of the public's compliance with the regime. With the diminishing need to tax constituents during this period ${ }^{51}$ and the growing capacity of the state to provide for their material welfare, the necessity of the racketeering cycle to legitimate the state lessened. Nevertheless, patronage of revivalism afforded the regime the ability to demonize continually its opposition in terms familiar to many in the Saudi populace. As numerous scholars have noted, the construction of political opponents of the Saudi regime as sources of insecurity for the movement persisted throughout the Cold War. ${ }^{52}$ The kingdom felt particularly vulnerable to the revolutionary ideologies of pan-Arabism and Nasserism that were reaching their dynamic zenith in the late $1950 \mathrm{~s} .{ }^{53}$ To counteract the threat domestically, Riyadh relied on the well-established tactic of stoking the movement's latent hostility toward

\footnotetext{
50 Ibid, p. 24.

${ }^{51}$ Asia Trade Hub (2015) Saudi Arabia. Asia Trade Hub. Available at: https://www.asiatradehub.com/saudiarabia/tax.asp, accessed 05/01/2017, accessed 05/01/2017.

${ }^{52}$ Authors who reference this factor include Commins, Vassiliev and al-Rasheed.

${ }^{53}$ Cronin, Tribes, Coups and Princes: Building a Modern Army in Saudi Arabia, Middle Eastern Studies, p. 17.
} 
innovation to reconstruct the emergent ideas of secular universalism into ontological threats, while simultaneously offering itself as a panacea against these same forces. In this narrative, Ba'athists, Arab nationalists, Nasserists and Communists were aggregated into a singular, godless menace. ${ }^{54}$ As under the second state, revivalist scholars rallied to discourage interactions between believers and those subscribing to ideologies which were claimed to 'contradict the spirit of Islam. ${ }^{55}$ In an echo of Abd al-Latif's comments on the Ottomans and the British, the future grand mufti of Saudi Arabia, Abd al-Aziz ibn Baz, declared that such unbelievers could not 'be fellow brothers of the Muslims,' that it was 'impermissible to consider them friends,' and that true believers should 'hate them for Allah. ${ }^{, 56}$ The focus of such constructions would shift again to a new emphasis on the Shi'a in 1979 with the decline of Arab nationalist regimes and the rise of revolutionary Iran. ${ }^{57}$

Contrasting against the infidelity of the external world, the state continued to claim itself as a bastion of traditionalism, even while overseeing its own rapid modernisation in contradiction to these credentials. As major initiatives began in the 1960s, future monarch Faisal ibn Abd al-Aziz stated that '[the] government is fully aware of the need to make serious efforts for the propagation and encouragement of Islam and its protections by words and deeds' ${ }^{58}$ and indicated that the regime was committed to '[maintaining] economic and

\footnotetext{
54 Nevo, J. (1998) Religion and national identity in Saudi Arabia, ibid.34(3), p. 46.

55 al-Rasheed, A History of Saudi Arabia, p. 191.

${ }^{56}$ Baz, A. a.-A. i. (1991) A Kafir cannot be a brother of a Muslim. The General Presidency of Scholarly Research and Ifta of the Kingdom of Saudi Arabia. Available at: http://alifta.com/Fatawa/FatawaChapters.aspx?languagename=en\&View=Page\&PageID=820\&PageNo=1\&Boo $k I D=14$, accessed 05/01/2017.

${ }^{57}$ Rich, B. (2012) Gulf War 4.0: Iran, Saudi Arabia and the complexification of the Persian Gulf equation, Islam and Christian-Muslim Relations, 23(4), pp. 471-86.

${ }^{58}$ Vassiliev, The History Of Saudi Arabia, p. 364.
} 
social stability within the existing religious and social framework. ${ }^{59}$ One of the primary means to achieving this became the sustainment of a heavy religious curriculum in national education, in which revivalist scholars were given leeway in order to perpetuate the movement's tenets in subsequent generations. ${ }^{60}$ Such a policy functioned in all stages of the racket: The state offering protections to the community in a commitment to preserving traditionalism; the acceptance of such offers by the majority of the revivalist elite and the community who in turn would reaffirm their own commitment to the state; the propagation of revivalist identity through the policy itself; and the use of the religious curriculum to continue to frame political rivals of the regime as threats to the movement.

Despite attempts to maintain a cycle of racketeering during this period, the contradictory behaviour of the regime in its pragmatic, a-ideological policies, in tandem with other factors such as economic downturn and policing crackdowns, could see its offers of protection rebuffed by revivalist subgroups in a manner that could lead to open confrontation. Two major incidents of this kind occurred during and around the Cold War. The first was the 1979 seizure of the Grand Mosque in Mecca by radical millenarian Islamists who had adopted the familiar title al-Ikhwān. While the motivations for this attack were diverse, ${ }^{61} \mathrm{a}$ major source of inspiration was the religio-cultural corruption of Saudi society by external influences, which the regime had failed in its duty to prevent. While occurring at the same time as other revolutionary movements in the Islamic world, Joseph Kechichian has argued that the ideology of al-Ikhwān was very closely aligned with many of the foundational

\footnotetext{
${ }^{59}$ Kostiner, J. \& Teitelbaum, J. (2000) State-Formation and the Saudi Monarchy, in: Kostiner, J. (eds) Middle East Monarchies: The Challenge of Modernity, pp. 136-37 (Berkley: University of California Press).

60 Prokop, M. (2006) The War of Ideas: Education in Saudi Arabia, in: Aarts, P. \& Nonneman, G. (eds) Saudi Arabia in the Balance, pp. 57-81 (London: Hurts and Company), p. 62.

${ }^{61}$ See further Hegghammer, T. (2011) The Meccan Rebellion: The Story of Juhayman al-'Utaybi Revisted, (Bristol: Amal Press).
} 
principles of revivalism. ${ }^{62}$ As a result, the organization's grievances against the state were formulated in many of these same terms, albeit in a radicalized and eschatological fashion. Another notable rebuff came in the form of the Saudi Islamist Sahwa (Awakening) movement, which confronted the regime in the early 1990s with a series of mass protests. As with the Ikhwān and the al-Ikhwān, the motivations of the Sahwa were varied, and ranged from poor economic opportunities, to the influence of a community of foreign Muslim Brotherhood political dissidents living inside the kingdom. ${ }^{63}$ Nevertheless, a key motivator behind the Sahwa's activities had been a perceived lack of commitment to upholding the tenets of revivalism, particularly focused on the decision to permit the entry of Western forces into the kingdom during the 1990/91 Gulf War and the resulting influence this had on Saudi society. Along with the experience of the Ikhwān, these two experiences showcased how racketeering could backfire on the regime. While each of these incidents had their own distinct set of idiosyncratic motivations, each showed how the state's failure to meet demands generated through the racketeering process could help stimulate mobilisation against it in a kind of religio-political Frankenstein's monster fashion. Today, this phenomenon may go some way in explaining the meteoric rise of the Islamic State, an organisation that itself claims to be pursuing a revivalist ideal of statehood similar to the discourse of the original Saudi state and which is reported to contain a disproportionately large number of Saudi citizens in its ranks. ${ }^{64}$

\section{Racketeering and the post-Arab Spring world}

\footnotetext{
62 Kechichian, J. A. (1986) The Role of the Ulama in the Politics of an Islamic State: the Case of Saudi Arabia, International Journal of Middle East Studies, 18(1), p. 59.

${ }^{63}$ See further Lacroix, Awakening Islam: The Politics of Religious Dissent in Contemporary Saudi Arabia..

${ }^{64}$ Middle East Monitor (2014) Saudis most likely to join ISIS, 10\% of group's fighters are women. Middle East Monitor. Available at: https://www.middleeastmonitor.com/news/middle-east/14758-saudis-most-likely-tojoin-isis-10-of-groups-fighters-are-women, accessed 05/01/2017.
} 
The process of racketeering has been central in Saudi efforts to contain the Arab Spring and a prominent feature of its geopolitical rivalry with Iran since 2011. The Saudi state continues to offer protection against unbelief and corruption to the estimated four million revivalists of its population who remain largely compliant with its patronage. ${ }^{65}$ At the same time, considerable state resources remain dedicated to cultivate religiosity in the public through education, moral and legal enforcement and mystification of the public sphere. The constructions of enemies as unclean threats to the integrity of the religion remains normal, as does the contradiction between the regime's religious commitments and many of its pragmatic policies concerning security, economic development and international relations.

As Saudi Arabia faced the Arab Spring in 2011, it sought to promote a sectarian narrative based on Shi'a ascendency that simultaneously would delegitimize oppositional groups and be readily accepted by the revivalist community. As Raihan Ismail puts it in the case of Bahrain, '[the] Saudi religious establishment [promoted] Sunni solidarity against the 'deviant' Shi'a, thus defining the...uprisings as a sectarian conflict.' ${ }^{66}$ A similar approach was applied at home against any political resistance in what Madawi al-Rasheed has termed 'sectarianism as counter-revolution.' ${ }^{67}$ Interpreted through the logic of racketeering, this approach sought to tap into the long-cultivated hostilities of revivalism toward religious heterogeneity by constructing challenges to the regime's authority as threats to the community, offering protections to this threat in exchange for the extraction of loyalty and support for the regime.

\footnotetext{
65 Izady, M. (2015) Demography of Religion in the Persian Gulf. Columbia University. Available at: http://gulf2000.columbia.edu/maps.shtml, accessed 05/01/2017.

${ }^{66}$ Raihan Ismail, 'The Saudi Religious Establishment and the Bahraini Uprisings ' in Change and Continuity in the Middle East and Central Asia (Australian National University: Australian National University, 2012). ${ }^{67}$ Al-Rasheed, M. (2011) Sectarianism as Counter-Revolution: Saudi Responses to the Arab Spring, Studies in Ethnicity and Nationalism, 11(3), pp. 513-526.
} 
Similar to the Arab Spring, the Saudi war with rebel Houthis in Yemen, interpreted by elites as a proxy conflict with Iran, has been portrayed as the latest front in the state's defence of the faith. ${ }^{68}$ In March of 2015, the Council of Senior Islamic Scholars declared the conflict as religious in nature and that any soldier dying in Yemen would be considered a martyr. In their statement they emphasised the sacred, defensive nature of the conflict, stating that '[one] of the greatest ways to draw closer to God almighty is to defend the sanctity of religion and Muslims.' ${ }^{69}$ Similarly, Grand Mufti al ash-Sheikh characterised the conflict as a drive to stop a 'Safavid march. ${ }^{70}$ As in many previous instances, the state sought to present its rivals, in this case the Shi'a Houthis, as un-Islamic corrupters of the faith, while vindicating and drawing support for its own actions as part of a wider effort to protect the integrity of the revivalist project.

\section{Conclusion}

Although the above model has reductionist features, it highlights a number of important logical continuities behind the Saudi state's use of religious revivalism as a tool of legitimation and governance. While the precise focus and idiosyncrasies of the Saudi state's relationship with the revivalist movement undoubtedly has altered since 1744 , the functional political outcome and overarching behaviour surrounding this patronage has displayed a remarkable cyclical consistency. This points to a four-point logic of instrumental protection racketeering on the regime's part, rather than adherence to ideological fidelity. Regardless of

\footnotetext{
${ }^{68}$ Akhbaar24 (2015) Tarifi: Jihad against the Houthi is a religious duty. Available at: http://akhbaar24.argaam.com/article/detail/186895, accessed 05/01/2017.

${ }^{69}$ Batrawy, A. (2015) Clerics In Saudi Arabia, Iran Cast Political Rivalry Over Yemen As Sectarian Struggle. The Huffington Post. Available at: http://www.huffingtonpost.com/2015/04/16/saudi-iran-rivalrysectarianism_n_7081880.html, accessed 05/01/2017.

${ }^{70}$ Sons, S. \& Matthiesen, T. (2016) The Yemen War in Saudi Media. Muftah. Available at: http://muftah.org/yemen-war-saudi-media/\#.WG3bcfl96Um, accessed 05/01/2017.
} 
the conditions in which it has found itself, the Saudi regime has striven to offer the revivalist movement a sense of protection against religious pluralism and heterogeneity, an offer that largely has been accepted since 1744 by the majority of the community in their compliance with the various systems of state extraction. Similarly, the state, regardless of whether it is in a position of prosperity or decline, has propagated revivalist identity to create a perennial demand for these same services of protection. Through this, the state consistently has sought to exploit this fertile socio-religious ground to construct its political rivals as sources of ontological insecurity that it then can use to justify renewed offers of protection. In the majority of these cases, the subjects of this securitization have little to no direct interest in interfering with revivalist doctrine, yet repeatedly, the revivalist community has accepted such a narrative. At the same time, despite the commitments engendered by the racket, the regime typically will opt for pragmatic policies of survival over maintaining ideological fidelity when forced to choose between the two. Thus the regime, despite its protestations to the contrary, has acted as the eminent stimulus for change, innovation and other activities that contradict the traditionalist focus of revivalist doctrine, a tendency that has led it to be perceived by numerous subgroups of adherents as the primary challenge to their religious integrity.

In short, to return to Tilly, the Saudi state provides a shield against the danger of ontological insecurity, but at the same time has significant control over when that danger appears and often has exercised this capacity to produce such threat when it sees political advantage in doing so. ${ }^{71}$ The implications of the Saudi state as a racketeer of revivalist identity are many. In one respect, the cycle helps to explain the state's general reluctance to oversee any major initiatives aimed at social liberalisation and interfaith relations. In regard to gender equality, the regime's ability to rely heavily on the profits of oil have helped to

\footnotetext{
${ }^{71}$ Tilly, War Making and State Making as Organized Crime, p. 171.
} 
retard the socio-economic impetus for reforms that would impart women with increasing agency in the public sphere, while at the same time its commitments to maintaining the traditional patriarchal values of revivalism as a form of protection present a degree of risk for any policy maker wishing to drive this process quickly forward. Likewise, the promotion of interfaith relations and tolerance both inside and outside the kingdom also is curtailed severely by the cycle of racketeering, particularly when the state feels under threat and sees a need to reinvigorate the practice. Prior to the Arab Spring, for example, then-King Abdullah sponsored a series of national dialogues to develop understanding between Sunni and Shi'a communities. Soon after the outbreak of protests in 2011 , however, Riyadh quickly reversed course on this initiative and instead framed the Shi'a as a religio-political threat to the revivalist community. As Matthiesen puts it, any semblance of mutual respect for diversity was 'replaced by bigotry and sectarian hatred. ${ }^{72}$ In this case, the temptation to construct the Saudi Shi'a as a potential threat to the wider revivalist community and harvest legitimacy for the regime was far greater than the prospect of a society in which the two groups existed harmoniously.

The protection racketeering system, repeatedly tested, has proven arguably the longest standing source of power and prestige for the Saudi regime. While the state may make minor concessions to external powers and advocates of human rights, social liberalisation and interfaith relations, it likely will continue to promote a hard-line revivalist identity in its citizenry in order to ensure ongoing survival. The racketeering system, for all its flaws, produced a net positive of results for the regime during times of political crisis and pressure, remaining an integral component of its absolutist hold on power. While the contradictions of this system have led to political confrontations in the past, the regime has managed to navigate all of

\footnotetext{
${ }^{72}$ Matthiesen, T. (2013) Sectarian gulf: Bahrain, Saudi Arabia, and the Arab Spring that wasn't, Stanford University Press), p. 80.
} 
these successfully. Given the current turmoil of the Middle East, it is difficult to predict with any certainty the challenges the Saudi state will face over the next few decades, but what the continuities of the past three centuries suggest is that racketeering will remain a central pillar of the regime's strategy for legitimation for the foreseeable future.

\section{Acknowledgements}

We would like to thank doctors David Commins, Remy Davison, Michael Humphrey, Catarina Kinnvall, Pete Lentini, Alana Sharp as well as our two anonymous reviewers for all the help, comments and input they contributed to this paper.

\section{Funding}

This work was supported by Monash University under a Post-Publication Grant.

\section{References}

Abd al-Wahhab, M. i. (2010) The Foundations of Islam: being a translation of Masa'il al-Jahiliyyah allati Khalafa fiha Rasulullah Ahla'l-jahiliyyah, (Birmingham: Dar as-Sunnah Publishers).

Abdallah, S. (N/D) The Evidences for the Ruling Regarding Alliances with the Infidels and Matters Related to It., (Najd: At-Tibyan Publications).

al-Maqdisi, A. M. (1984) Millat Ibrahim, (at-Tibyan Publications).

Akhbaar24 (2015) Tarifi: Jihad against the Houthi is a religious duty. Available at: http://akhbaar24.argaam.com/article/detail/186895, accessed 05/01/2017.

al-'Uthaymin, A. A. S. (2009) Muhammad ibn 'Abd al-Wahhab: The Man and his Works, (London: I.B. Taurus and Co).

al-Atawneh, M. (2009) Is Saudi Arabia a Theocracy? Religion and Governance in Contemporary Saudi Arabia, Middle Eastern Studies, 45(5), pp. 721-737. 
al-Juhany, U. M. (2002) Najd before the Salafi Reform Movement: Social Political and Religious Conditions during the 3 Centuries Preceding the Rise of the Saudi State, (Berkshire: Ithaca Press).

al-Rasheed, M. (2002) A History of Saudi Arabia, (Cambridge: Cambridge University Press).

al-Rasheed, M. (2007) Contesting the Saudi State, (New York: Cambridge University Press).

Al-Rasheed, M. (2011) Sectarianism as Counter-Revolution: Saudi Responses to the Arab Spring, Studies in Ethnicity and Nationalism, 11(3), pp. 513-526.

Alsaid, T. (2013) Relationship between state and religion in Saudi Arabia: the role of Wahabism in governance, Contemporary Arab Affairs, 6(3), pp. 376-403.

Asia Trade Hub (2015) Saudi Arabia. Asia Trade Hub. Available at: https://www.asiatradehub.com/saudiarabia/tax.asp, accessed 05/01/2017.

Batrawy, A. (2015) Clerics In Saudi Arabia, Iran Cast Political Rivalry Over Yemen As Sectarian Struggle. The Huffington Post. Available at: http://www.huffingtonpost.com/2015/04/16/saudi-iran-rivalrysectarianism_n_7081880.html, accessed accessed 05/01/2017.

Baz, A. a.-A. i. (1991) A Kafir cannot be a brother of a Muslim. The General Presidency of Scholarly Research and Ifta of the Kingdom of Saudi Arabia. Available at: http://alifta.com/Fatawa/FatawaChapters.aspx?languagename=en\&View=Page\&PagelD=820\&PageNo=1\&Boo kID=14, accessed 05/01/2017.

Commins, D. (2006) The Wahhabi Mission and Saudi Arabia, (New York: Palgrave Macmillan).

Cronin, S. (2013) Tribes, Coups and Princes: Building a Modern Army in Saudi Arabia, Middle Eastern Studies, 49(1), pp. 2-28.

DeLong-Bas, N. J. (2004) Wahhabi Islam: From Revival and Reform to Global Jihad, (New York: Oxford University Press).

Firro, T. K. (2013) The Political Context of Early Wahhabi Discourse of Takfir, Middle Eastern Studies, 49(5), pp. 770-789.

Garfield, R. M. \& Neugut, A. I. (1997) The Human Consequences of War, in: Levy, B. S. \& Sidel, V. W. (eds) War and Public Health, pp. 27-38 (New York: Oxford University Press).

Goldberg, J. (1982) The 1913 Saudi occupation of Hasa reconsidered, Middle Eastern Studies, 18(1), pp. 21-29.

Habib, J. S. (1978) Ibn Sa'ud's warriors of Islam: The Ikhwan of Najd and their role in the creation of the Sa'udi Kingdom, 1910-1930, (London: Brill).

Hegghammer, T. (2011) The Meccan Rebellion: The Story of Juhayman al-'Utaybi Revisted, (Bristol: Amal Press).

Izady, M. (2015) Demography of Religion in the Persian Gulf. Columbia University. Available at: http://gulf2000.columbia.edu/maps.shtml, accessed 05/01/2017.

Juergensmeyer, M. (1994) Religious nationalism confronts the secular state, Oxford University Press).

Kechichian, J. A. (1986) The Role of the Ulama in the Politics of an Islamic State: the Case of Saudi Arabia, International Journal of Middle East Studies, 18(1), pp. 53-71.

Keltie, J. S. \& Epstein, M. (1921) The Statesman's Yearbook, (New York: The Macmillan Company). 
Kinnvall, C. (2004) Globalization and Religious Nationalism: Self, Identity, and the Search for Ontological Security, Political Psychology, 25(5), pp. 741-767.

Kjorlien, M. L. \& Michele, M. L. (1994) State and Religion in Saudi Arabia, The Arab Studies Journal, pp. 36-64.

Kostiner, J. (1985) On instruments and Their Designers: The Ikhwan of the Najd and the Emergence of the Saudi State, Middle East Studies, 21(3), pp. 298-323.

Kostiner, J. (1990) Transforming Dualities: Tribe and State Formation in Saudi Arabia, in: Khoury, P. S. \& Kostiner, J. (eds) Tribes and State Formation in the Middle East, pp. 226-249 (Berkley: University of California Press).

Kostiner, J. \& Teitelbaum, J. (2000) State-Formation and the Saudi Monarchy, in: Kostiner, J. (eds) Middle East Monarchies: The Challenge of Modernity, pp. 131-149 (Boulder: Lynne Reinner Publishers, Inc).

Lacroix, S. (2011) Awakening Islam: The Politics of Religious Dissent in Contemporary Saudi Arabia, (Massachusetts: Harvard University Press).

Mann, M. (1984) The autonomous power of the state: its origins, mechanisms and results, European Journal of Sociology / Archives Européennes de Sociologie, 25(02), pp. 185-213.

Matthiesen, T. (2013) Sectarian gulf: Bahrain, Saudi Arabia, and the Arab Spring that wasn't, Stanford University Press).

Matthiesen, T. (2015) The Other Saudis, (New York: Cambridge University Press).

Middle East Monitor (2014) Saudis most likely to join ISIS, $10 \%$ of group's fighters are women. Middle East Monitor. Available at: https://www.middleeastmonitor.com/news/middle-east/14758-saudis-most-likely-tojoin-isis-10-of-groups-fighters-are-women, accessed 05/01/2017.

Mitzen, J. (2006) Ontological Security in World Politics: State Identity and the Security Dilemma, European Journal of International Relations, 12(3), pp. 341-370.

Nevo, J. (1998) Religion and national identity in Saudi Arabia, Middle Eastern Studies, 34(3), pp. 34-53.

Niblock, T. (2004) Saudi Arabia: Power, Legitmacy and Survival, (Hoboken: Taylor and Francais).

Prokop, M. (2006) The War of Ideas: Education in Saudi Arabia, in: Aarts, P. \& Nonneman, G. (eds) Saudi Arabia in the Balance, pp. 57-81 (London: Hurts and Company).

Quataert, D. (2005) The Ottoman Empire, 1700-1922 (Cambridge: Cambridge University Press).

Rich, B. (2012) Gulf War 4.0: Iran, Saudi Arabia and the complexification of the Persian Gulf equation, Islam and Christian-Muslim Relations, 23(4), pp. 471-486.

Scott, J. C. (1999) Seeing Like a State: How Certain Schemes to Improve the Human Condition Have Failed, (Yale: Yale University Press ).

Shahi, A. (2013) The Politics of Truth Management in Saudi Arabia, (Hoboken: Taylor and Francais).

Sons, S. T., Matthiesen (2016) The Yemen War in Saudi Media. Muftah. Available at: http://muftah.org/yemenwar-saudi-media/\#.WG3bcfl96Um, accessed 05/01/2017.

Steinberg, G. (2006) The Wahhabi Ulama and the Saudi State: 1745 to Present, in: Aarts, P. \& Nonneman, G. (eds) Saudi Arabia in the Balance, pp. 11-34 (London: C. Hurst an Co.). 
Tilly, C. (1985) War Making and State Making as Organized Crime, in: Evans, P., Rueschermeyer, D. \& Skocpol, T. (eds) Bringing the State Back In, pp. 169-187 (Cambridge: Cambridge University Press).

Toth, A. B. (2005) Tribes and Tribulations: Bedouin Losses in the Saudi and Iraqi Struggles Over Kuwait's Frontiers, 1921-1943, British Journal of Middle Eastern Studies, 32(2), pp. 145-167.

Trofimov, Y. (2007) The Siege of Mecca, (New York: Doubleday Broadway Publishing Group).

Tyler, T. R. (2006) Why people obey the law, (New Jersey: Princeton).

Vassiliev, A. (2000) The History Of Saudi Arabia, (London: Saqi Books).

Vlahos, M. (2008) Fighting Identity: Sacred War and World Change (Westport: Praeger).

Wagemakers, J. (2012) The Enduring Legacy of the Second Saudi State: Quietist and Radical Wahhabi Contestations of al-Wala' wa-I-Bara', Middle East Studies, 44(1), pp. 93-110.

White, M. (2012) Selected Death Tolls for Wars, Massacres and Atrocities Before the 20th Century. Available at: http://necrometrics.com/pre1700a.htm\#30YrW, accessed 24/03/2015.

Wynbrandt, J. (2004) A Brief History Of Saudi Arabia, (New York: Checkmark Books).

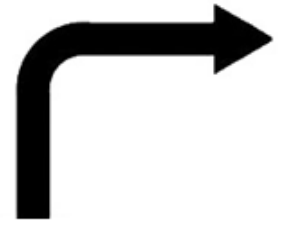

Stage 4: State activities generate ontological insecurity amongst revivalist community.
Stage 1: State offers protections

against ontological insecurity to revivalists.

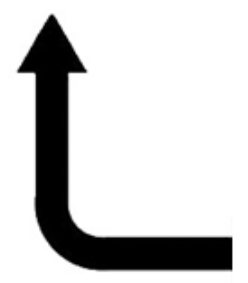

Stage 3: State propagates revivalist identity.

Stage 2: Protections accepted. State gains legitimacy and extraction. 